\title{
Crisis? What (Type) of Crisis? The overlapping problems of the European Union
}

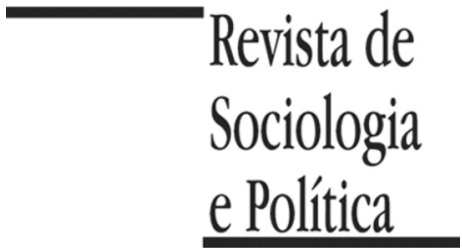

DOI: $10.1590 / 1678-987314225004$

\section{Kai Lehmann}

\begin{abstract}
It is common today, even in the European media, to treat the current crisis of the European Union almost exclusively as an economic crisis. The present article pretends to show that such a focus is not only wrong but is indeed dangerous for the future development of the European Union as a whole. The article will argue that the present economic crisis simply aggravated - and a lot - a crisis of legitimacy through which the European Union has been passing for some time. Showing that the anti-European tendencies which are spreading throughout the countries of the continent threaten the very future of the European project, the article will make suggestion on reforms for the future development of the EU, alerting to the necessity to finally elaborate once again a coherent argument for the continuation of the European integration process which puts the European population at the heart of the political process instead of just austerity.
\end{abstract}

KEYWORDS: European Union; multiple crisis; adaptive action; austerity; European integration.

Recebido em 30 de Julho de 2013. Aprovado em 30 de Agosto de 2013.

\section{Introduction ${ }^{1}$}

\footnotetext{
${ }^{1}$ I would like to thank the anonymous reviewers of the Revista de Sociologia e Política for their contributions for this article.

${ }^{2}$ As one senior EU diplomat admitted to the author during an 'on background' interview.
}

7 here can be little dispute that the European Union is passing through a severe crisis. Even ardent pro-Europeans and EU diplomats admit, or be it 'off-the-record', that the EU is currently facing extreme difficulties. $^{2}$ Yet, when one talks about the EU crisis at the moment, the main focus is still on the economic difficulties which are particularly acute in the Eurozone and, within that, in a group of countries on the southern periphery of the continent, such as Greece, Spain, Portugal and Cyprus, Ireland being the geographic exception.

The argument put forward in this article is that, despite the undoubted severity of the crisis, the current economic difficulties faced by some members of the European single currency merely add to a much deeper, and much more political, crisis faced by the European Union as a whole. It will be shown that the economic difficulties are both partially the result of this deeper political crisis, and a factor in the deepening of the same, one which, as will be shown, has the potential to, at least, seriously undermine the prospects for further European integration in the future and, therefore, the future of the European Union itself.

In order to confront this crisis, the article will show, the EU, and those who take decisions within it, will have to move away from their very narrow definition of the problems they are confronting and begin seeing them as part of a continuous process which will only be steered into calmer waters again if the EU takes some tough strategic decisions about where the organization wants to go and why it actually still exists. 
After a brief review of the current problems and the 'state of play' in addressing them, the article will go on to contrast the EU's current approach to its problems with an approach informed by the concept of adaptive action, developed by Eoyang and Holladay (2013). Using the three key questions that inform adaptive action (What? So what? Now what?), the article will reconceptualize the crisis currently confronted by the EU and will make some specific suggestions as to how it should act and what it should do to get through its current difficulties.

\section{The context: the European Union and the economic crisis}

${ }^{3}$ See Trading Economics (2014a).

${ }^{4}$ See Trading Economics (2014b).

${ }^{5}$ See Global Property Guide (2014).

${ }^{6}$ For a timeline of the crisis and details on the policy actions taken, see European Central Bank (2014).
In many ways the economic nature of the crisis confronted by the European Union seems almost too obvious. One brief look at just some of the indicators which measure Europe's economic performance shows that, clearly, the continent and, as such, the European Union, is confronting awesome challenges. Just to give some examples: between January and March 2013, Greece, perhaps the worst hit country of all in Europe, notched up its $19^{\text {th }}$ (!) consecutive quarter of negative growth. ${ }^{3}$ In Spain, despite a small drop in unemployment in June 2013, still over a quarter of the workforce are out of a job, with more than $50 \%$ of young people not economically active. ${ }^{4}$ In Ireland, some areas have seen property prices fall over $50 \%$ since $2007^{5}$ whilst several countries, again with Greece as leader amongst them - faced an accumulated public debt far exceeding national GDP (Finanzkrise: Euro Länder häufen neue Schulden an, 2013).

Since all of these countries are bound together by the fact that they take part in a monetary union and share a single currency, this has meant that the 'sovereign debt crisis' (as it has been termed by some, such as Lane (2012)), turned itself into a severe crisis for the Eurogroup in particular but, as will be argued, by the European Union as a whole, which was faced by numerous and often contradictory - pressures to 'get a grip' on the situation, lest a process of 'contagion' affected other or all Eurozone countries and EU member states. On the one hand, the European Union as a whole needed to safeguard its own single currency and ensure its stability. To do so, it was critical that member countries did not default on their debt which would have meant their exit from the single currency with unpredictable consequences both for the currency itself and the wider international financial system. It was therefore critical to ensure the liquidity of both individual countries and the financial system as a whole. On the other hand, it was seen as necessary to radically reduce the indebtedness of Eurozone countries. In some cases (Greece and Italy prominent amongst them), policy-makers therefore faced the unenviable task of reducing the indebtedness of the state at a time of a severe economic recession. ${ }^{6}$

Bearing in mind the above, it is perhaps not surprising that the European Union chose to define its problems through an economic prism and focus its anti-crisis policies primarily on economic and fiscal indicators. In order to ensure that no Eurozone state default on its debts, the so-called 'Troika' of the European Union, the European Central Bank and the International Monetary Fund (IMF) have demanded, in some cases, deep cuts to public spending (and, as a result, public services) in return for so-called bail-out funds designed to ensure that states were in a position to meet ongoing financial commitments. The Economist (No Going Back 2009)was not the only outlet to call the sums involved 'breathtaking', with the initial Stabilization fund consisting of no less than 750bn euros. This fund has been followed by the setting-up of a perma- 
${ }^{7}$ For a more detailed overview of the measures taken, see Cini and Borragán (2013). nent 'stabilization mechanism', as well as the tightening of the rules governing the single currency and moves to create both some type of economic union as well as a banking union. ${ }^{7}$

Without doubt, these actions have had considerable impact and achieved their overriding initial objective of stopping Eurozone countries going into default. However, many commentators and analysts doubt whether enough has been done to resolve the crisis or whether the crisis is in fact over, as proclaimed by French president Francois Holland recently, with The Economist (Till default do us part 2013) again leading the charge.

\section{Analyzing and evaluating the crisis from an EU perspective}

Over the last few years a considerable amount of literature has emerged analyzing both the origins of - and the EU's response to - the crisis which has befallen it from an economic perspective, with even American Congress producing a detailed study, illustrating the global impact the crisis has had (Nelson et al. 2012). Within this literature one can distinguish between two different aspects of analysis: one essentially asks how the EU got itself into the situation it is in whilst the other focusses more on whether it has done enough to get itself out of this situation and what else needs to be done in order not to confront such a situation again in the future.

Amongst those who have focused on the question of how we got here, several core arguments can be identified which will be crucial in the later argument about the political crisis faced by the EU as a whole. From a purely economic point of view, several specialists have pointed out that the European Union as a whole never represented a so-called 'optimum currency area'. According to this argument, both the macro-economic circumstances as well as the economic policies pursued by national governments were simply too different as to be able to form a stable and durable currency union as, for instance, Bayoumi and Eichgreen (1993) have argued. Following this line of argument, it can be said that the European Union itself was aware of this problem when it stipulated the pre-conditions a country had to fulfill before being considered for membership of the single currency, as well as the rules to be followed once 'inside the club': these rules, as spelled out in the so-called Stability and Growth Pact, at first glance, seemed unambiguous, as Nugent (2010) showed. They committed the members to the pursuit of low inflation and supposedly put a cap on the amount of public debt a government could accumulate $(60 \%$ of GDP) and the annual budget deficits it would be allowed to run (3\% of GDP). The fact that breaches of these rules could be punished and that Eurozone monetary policy was also to be overseen by an entirely independent European Central Bank, the ECB, was also intended to ensure that the Eurozone would become progressively more coherent internally.

However, there is a general consensus, - and subsequent events would suggest this fact to be obvious, - that these rules were simply not good enough on the grounds that they were not underpinned by governance mechanisms strong enough to ensure compliance with the very rules the EU itself established. Kramer (2012, p. 83) described the governance system of the single currency as 'fragile', seeing as it was dependent on the agreement and cooperation of the same member-states it was meant to control. In simple terms, member-states decided whether to punish member-states for breaching the rules of the single currency. Wallace, Pollack and Young (2010) make similar arguments. 

${ }^{8}$ Senior EU diplomat, intervie-
wed in June 2013.
Kramer (2012, p. 83) concludes that this fragility was the result of essentially political factors. According to him the two main drivers and architects of economic and monetary union, former German chancellor Helmut Kohl and the late French president Francois Mitterand, 'acted as statesmen, not economists' in setting up monetary union, seeing it as an instrument to anchor a reunified Germany in the European Union in the aftermath of the Cold War whilst advancing the cause of European integration.

This interplay between economic and political factors can be seen throughout the history of the single currency. Critically, for instance, the inclusion of Greece in 2001 was seen as a purely political decision, whilst underlining the weakness of the enforcement mechanisms, bearing in mind that Greece was in no position to fulfill the convergence criteria, joining basically by 'cooking the books' (Böll et al. 2012). Equally significant was the fact that both Germany and France broke the the rules of the Stability and Growth Pact. Yet, rather than being punished, the pact was amended to make it more flexible, bowing to political pressure. All of this led Böll et al. (idem) to entitle their overview of the origins of the euro 'Operation self-deceit'. Ever since then what has been lacking is 'a European government which could analyze problems from a European perspective' (Kramer 2012, p. 83).

From that point of view, many saw the crisis of monetary union as inevitable in the absence of an accompanying political union. One senior EU diplomat put it this way: 'I think [the crisis shows that] we have reached the end of the line as far as what we can do with intergovernmentalism'. ${ }^{8}$ This is crucial since it points to the fact that the current crisis of the Eurozone is a result of a bigger crisis of the European Union, namely the inability of its political leaders to get the 'big things right' because of a lack of political agreement, an argument forcefully made by Bittner (2010). More will be said on this below.

Another group of analysts have looked at the results of EU policies in the response to crisis, basically austerity in return for bailout funds. Interestingly, their conclusions point to the same problems already talked about above.

Generally speaking, the results of the EU's policies have been deeply disappointing. As Blyth (2013, p. 42) has pointed out, despite often deep cuts in public spending, 'Portugal's debt-to-GDP ratio increased from $62 \%$ in 2008 to $108 \%$ in 2012. Greece's debt-to-GDP ratio climbed from a $106 \%$ in 2007 to $170 \%$ in 2012.' Incredible as it might seem, the situation worsened further up to 2013, with the debt-to-GDP ratio of the Eurozone as a whole reaching 92\%, '4\% higher than in 2012' (Finanzkrise: Euro Länder neue Schulden anhäufen 2013). This scenario has led some, like Krugman (2012), to argue that, not only had the European Union failed to deal with the problems in hand, but it had actually made a bad situation worse: it had managed, just like several other political decision-makers around the world, to turn a recession into a depression, with devastating consequences mainly for the poorest countries and the poorest segments of the population.

In a further critique, some analysts have argued that, apart from austerity taking billions of euros out of the economy at precisely the wrong time, the actions have also left the broader problems that contributed to the crisis unresolved. For instance, whilst it may well have been necessary to cut public expenditure in Greece, this will mean very little in the long-term as long as 'structural and fiscal problems remain' (Subacchi \& Pickford 2012, p. 3). In other words, apart from cutting spending, very little has been done to address the structural root causes that led to the crisis in the first place, both at national 
${ }^{9}$ Interview with EU diplomat, June 2013. ${ }^{10}$ From a seminar held in 2012
and attended by the author. and at European level. Crucially, the EU has been strongly criticized in this respect for not taking sufficient account of the particular circumstances of each country, adopting instead a broad-brush macro-level approach to dealing with the crisis. For instance, it has been argued that only Greece had a real debt-crisis. In Spain and Ireland, by contrast, there was a housing bubble whilst Cyprus has recently faced a liquidity crisis in the banking sector. According to this line of argument, made by Krugman (2012) amongst others, each one of these cases requires a nuanced policy approach. So far, this has not been forthcoming from the European Union, pointing once again to the political crisis through which it is passing as a whole.

This begs the question as to why the European Union has not been able to develop a policy-strategy which would bring the crisis under control and here one, once again, comes to the political aspects of the entire European project.

The 'modus operandi' of the EU during the crisis was neatly summed up by Copsey and Haughton (2012, p. 1) when they attested that European leaders 'lurched from one emergency summit to another' in a desperate search for stability in the Eurozone. Even EU diplomats admit that the spectacle is often unedifying, but point out that the way the organization operates is the result of its unique features: 'We need to do many things together but, in the end, the EU has 27 (now 28) members, all of them sovereign states'. ${ }^{9}$ In other words, the very success of the EU (as measured by its continuous expansion) leads to deep fault-lines in its functioning and, seemingly, diminishing prospects for future integration even in the face of severe crises like the current one.

This fact, for some, puts the very future of the European Union as it is currently constituted in doubt. Tsoukalis (2011) pointedly entitled his review of EU activities in 2010 'the shattering of illusions'. Jo Johnson et al. (2012) at Chatham House, one of the most respected think tanks for international politics in Europe, asked if the objective of 'ever closer union' enshrined in the Maastricht Treaty was still attainable, and, again, Copsey and Haughton (2012, p. 1) stated bluntly that 'crisis appears to be the new normal state of the European Union'.

Some have gone further and argued that the European Union has almost always been in crisis, but that the nature of the crisis makes the current one more dangerous for the future of the integration process. As Hodson and Puetter (2013, p. 367) have put it: 'Looking back on the history of European integration, it is difficult to remember a time when the European Union or its predecessors were not facing a crisis of one sort or another'.

What is different this time, though, is the particular division between 'crisis states' and 'non-crisis states'. The first group is made up generally of small states on the southern periphery of the European Union, whilst the latter group consists, generally, of the rich, northern states. As one keen and long-standing observer of European affairs noted at a seminar, this particular division is something new in the history of European integration and has put into question one of the key principles upon which the process of integration has always rested since its inception in the 1950s: solidarity. If, according to this observer, this pillar of mutual solidarity now breaks away, the very future of the integration project would be in doubt. ${ }^{10}$

Several commentators have pointed to Germany and its posture as the key reason for the erosion of solidarity between EU (and in particular, Eurozone) member states. Mallaby (2012), for example, stated bluntly that Europe's was 
${ }^{11}$ Interview with EU official, June 2013. an 'optional catastrophe' and that its fate now lay 'in Germany's hands' which needed to develop strategies for growth instead of merely focusing on austerity. Such narrow focus, according to Tooze (2012) will lead to stagnation for Germany in the future.

In view of all these difficulties, some have called for further integration. As one senior EU official put it: 'We need a political union'. ${ }^{11}$ Berggruen and Gardels (2013, p. 134) agree, calling for a concerted effort 'toward a federal union'. However, others have stated that the current difficulties merely underline the folly of embarking on the path towards a single currency in the first place and warn that any move towards further integration, such as a fiscal union would merely undermine the future prospects for the organization still further, creating deep divisions between those inside the Eurozone and those outside, making coherent political action in response not just to economic difficulties but to a host of others issues more difficult (Milne 2013).

Following this line of argument, the creation of the single currency and its deficient execution has led not only to deep divisions between rich northern and poor southern countries inside the group of single-currency countries but also between those countries which use the single currency and those outside it. Again, looking at the recent history of European integration, the fact that such divisions emerged should not really have come as a surprise. So-called 'opt-outs' that some countries have in some policy areas have become increasingly common, one could even say normal, ever since the very Maastricht Treaty which instigated economic and monetary union as Dinan (2004) has shown. In many ways, bearing in mind the increasing complexity of the EU, opt-outs constituted the only way to continue some type of integration, as Walton and Zilonka (2013) have argued, but this has come at a cost, as the above discussion shows, in terms of coherence.

The EU, therefore, confronts multiple crises: a deep economic one which manifests itself most profoundly in some of those countries that use the European single currency, but also a significant political one which affects the entire EU and which needs to be overcome in order to actually effectively deal with the economic crisis. Failure to do so has accelerated two other crises: a crisis of legitimacy and a crisis of direction which evolve around the question what the European Union is actually for. It is these aspects which, as will be shown now, exist semi-independently from the economic crisis, which make the current situation so threatening for the future of the EU.

\section{European integration, but for what? The crisis of direction and leadership}

There can be little doubt that the failure of the European Union to effectively deal with the economic crisis has had an adverse effect on the legitimacy of the organization. According to the EU's own public opinion surveys, only just over 1 in $5 \mathrm{EU}$ citizens believes that the European Union is capable of resolving the crisis through its actions (European Commission 2013, p. 3). Equally worrying, more than half of all EU citizens believe that the worst of the economic crisis is still to come, an astonishing number bearing in mind the length of time the crisis has been ongoing (IBID).

Recent surveys have also underscored the EU's north-south divide already touched upon above, with only 1\% of Spaniards and 2\% of Cypriots and Greeks expressing confidence about the state of their country's economy, a figure which shoots up to $80 \%$ and $77 \%$ respectively when the same question 
${ }^{12}$ Remark made in conversation with author during a seminar about the economic crisis. is asked of Swedes or Germans (Fox 2013). Critically in terms of the EU's future prospects, $89 \%$ of Cypriots and Greeks contend that their voices are not being heard inside the European Union (IBID).

The upper echelons of the European Union's political leadership are aware of these problems. As one EU ambassador put it: 'It is critical to solve the crisis in order to win back the trust of the population'. ${ }^{12}$ However, research done by Serricchio, Tsakatika and Quaglia (2013) has found that euro-skepticism has many causes, of which the economic crisis is one, but not the most important one. Whilst the rise in Euro-skepticism is most pronounced in those countries hardest hit by the economic crisis and whilst there has been a steady increase in skepticism towards the European Union since the onset of the economic crisis - nevertheless 'national identity and political institutions play an increasingly important role in explaining public euro-skepticism' (idem, 51).

The reference to political institutions is critical in this respect since other authors have also argued that skepticism towards such institutions is both a generalized phenomenon and one which pre-dates the economic crisis. As Wessels (2007) pointed out, there is increasing skepticism towards authorities and regimes in general. Applied to the European Union, left unchecked, such tendencies have the potential to significantly undermine support for the general project of European integration.

Critically this indicates that the economic crisis 'merely' accelerated a process which has been ongoing for some time, suggesting that the EU has some deep-seeded problems which go way beyond resolving the economic problems it is currently confronting. For a growing number of commentators the problems are actually very basic but very fundamental: It is the question of what the European Union is actually for. In the Chatham House debate (Jo Johnson et al. 2012), one participant, John Peet, argued that the European Union urgently needed to confront issues of democracy, legitimacy and accountability brought into sharp focus by the economic crisis (idem, p. 2). Another, John Jungclaussen, went further saying that the crisis of legitimacy is brought about by a lack of purpose and direction: 'There is no narrative anymore', as he put it (idem, p. 3).

Yet, such a narrative has been fundamental in sustaining the European Union over the decades and instrumental in explaining a large part of its success. In fact, as Manners (2008, p. 65) demonstrates, the idea of safeguarding peace on the European continent was perhaps the overriding narrative through which the process of economic integration, started with the creation of the European Coal and Steel Community (ECSC) in the Treaty of Paris, could be justified and sustained both practically and normatively since 1951. "The success of European integration in achieving peace and sustaining this narrative 'changed what passes for normal in world politics' (ibidem).

As Lehmann (2012) has argued, the successful reconciliation between France and Germany, the stability and economic prosperity in Western Europe during the Cold War and the generally successful transition of Eastern Europe from Communism to capitalism and liberal democracy during the 1990s (with the obvious and terrible exception of the former Yugoslavia) meant that the EU was able to sustain this narrative over several decades. In fact, in its attempts to raise its foreign policy profile from the 1990s onwards, the EU pursued a clear discourse of serving as a model for integration which could be reflected and copied around the world. The eventual entry of the vast majority of the former communist states of Eastern Europe, including in 2004 and 2013 


\footnotetext{
${ }^{13}$ Interview with senior EU official, June 2013.

${ }^{14}$ Remark made during a seminar about the economic crisis in 2012.
}

respectively the former Yugoslav republics of Slovenia and Croatia, also bears testament to the enduring popularity of the EU with its immediate neighbors.

The award of the Nobel Peace Price to the European Union in 2012 in recognition of its achievements in preserving peace represented, in many ways, the culmination of this process but, as has been argued, also served as a warning that the future of the organization dependent on it being able to redefine its purpose and develop a new narrative. The European Union urgently needs to find an answer to the question being repeatedly asked during demonstrations in Greece, Spain and elsewhere: 'What can Brussels, and Europe, do for us' (Jo Johnson et al., p. 3).

Some senior EU figures acknowledge this as a serious problem. One of them said: 'I think multilateralism is in a big crisis generally [and as such] we have to admit that our influence outside Brussels is rather limited'. ${ }^{13}$ The EU ambassador already cited earlier also admitted these difficulties: 'I agree that we as an organization are not very good at selling ourselves'. ${ }^{14}$

To overcome these problems, both argued that 'leadership' was needed. However, as will be shown now, getting such leadership will be very difficult, principally because the European Union conceives its own crisis in a way which makes its solution more difficult.

\section{Re-defining the European crisis: What? So what? Now what?}

As already shown above, in its definition and management of the crisis the European Union has focused almost exclusively on the economic aspects of it. In fact, one can go even further and argue that, for the EU, the crisis revolves around one key variable: public debt. So, in response to the question what problem the European Union is facing, it has consistently responded that some of its member states are facing a fiscal problem which has an impact on one particular area of integration: its monetary union of which not all of its member states are a part. In terms of so what does that mean, as shown above, it has meant that political action has to focus on changing a couple of key variables, especially reducing the level of public indebtedness of the most seriously affected countries. This, in turn, would restore the confidence of the financial markets, thereby encouraging investment and return those countries (and the Eurozone as a whole) to growth. As such, in response to the question of now what, the logical answer has been to cut state expenditure in those countries most seriously affected by the 'debt crisis', 'restructuring' the economies in the process. Having brought the 'debt problem' 'under control', the aim would then need to be to create new, more effective rules in order to maintain this situation as stable as possible for as long as possible and stopping the problems that led to the crisis from reoccurring. In short, the EU has defined its current crisis in a limited and classic 'linear' fashion, seeing an unfavorable situation $a$ which, through the application of specific policies to change a couple of clearly definable variables, could lead to favorable situation $b$, which would then need to be maintained for as long as possible, usually through the 'tightening' of the rules which govern the particular policy area.

However, as has been shown, this approach has been questioned on two fundamental points: First, its effectiveness has been called into question on the grounds that, so far, it has not achieved the desired results. Second, it has been argued that this approach ignores some of the far deeper problems that the European Union as a whole faces and which have been exacerbated by the 
${ }^{15}$ Remark made at a seminar about the economic crisis in response to a question by the author.

${ }^{16}$ For a detailed discussion of this term and what it means, see Eoyang and Holladay (2013).

\footnotetext{
${ }^{17}$ Interview with EU analyst,
} July 2013. economic crisis but were not created by it. As shown, the EU actually faces an interdependent mix of political and economic problems which, in many ways, have led to the specific problems now confronted in relation to monetary union but which, it would seem, the current approach is ill equipped to tackle.

Challenged on this very point by the author, the response of one EU ambassador actually gave rise to the idea for the present article. The ambassador responded: 'I know that we have deeper problems, but first we have to solve the economic crisis, then we can deal with the other things' (my emphasis). ${ }^{15}$ In other words, the sequential approach applied to the economic crisis is also being applied to the political and legitimacy crisis recognized by the EU. Solving one problem will logically lead to a solution for the other problem.

As will be shown now, however, such an approach does not recognize the fundamental nature of the problems confronted by the EU and, if continued to be pursued, will actually worsen those problems. To be able to get hold of its deeper problems of legitimacy, declining popularity and political stagnation, the EU will need to stop thinking sequentially and start thinking and acting adaptively. ${ }^{16}$ Adaptive action will allow for the construction of a framework for seeing, understanding and influencing patterns in what is a complex and changeable crisis situation which extends across several levels of analysis and which moves forward through the interaction between interdependent and, therefore, only semi-autonomous agents across time and space, meaning that one is confronted with 'continuous action' (Lichtenstein et al. 2006). In practice, this means very different responses to the questions What? So what? Now what? as well as a need for constant evaluation and adjustment of policies.

What is essentially trying to uncover the dynamics which underpin, govern and sustain the current patterns, in our case the crisis of the European Union. As shown, for the EU itself, these dynamics limit themselves to the fiscal/economic crisis of some specific countries. Yet, as outlined above, for many others the current fiscal crisis is the result of - and sustains - a much broader crisis. In fact, as shown, even some senior EU diplomats have recognized the need for a fundamental reform of the 'EU way' of doing things, arguing for a political union.

Whilst there are obviously differing opinion about that particular conclusion, there is a broad consensus amongst many observers that, in the words of Bittner (2010, p. 19) the EU is doing 'small things too big and big things too small.' In the words of one other observer, 'the EU focusses on small things because it is no longer able to agree on the strategic issues it faces'. ${ }^{17}$

In basic terms, the European Union no longer knows what it is for, it no longer has any clear sense of why it actually exists and, crucially, why it should exist. In practical terms, there is, clearly, a desire on the part of the EU and most of its member states to, for instance, save the single currency and sustain the single market. However, for some countries, such as the UK - this appears to be an end in itself in order to preserve stability and the advantages that the single market brings. For those, however, who see them as part of something bigger, as something normative, it seems increasingly difficult to make a coherent connection between those projects and the broader strategic aims of the European Union. As already touched upon above, this problem has even been recognized by some senior EU officials but has not been addressed coherently by the organization as a whole. In terms of what do we see when one looks at the EU today, then, it is an organization which is drifting; in permanent crisis mode unable to face the future. 
This leads one to the second part of the what question: What has led to and caused - the emergence of the current pattern? In practical terms, as was already discussed earlier, it seems clear that the set-up of the institutional and political arrangements of monetary union, its governance structures, were inadequate to deal with the complexities inherent in a currency union between very different sovereign states. However, this underlines the fact that the way the European Union 'does things', as a general rule, has also been inadequate. As shown above, Greece's participation in monetary union, for instance, was an almost entirely political, as opposed to an economic, decision. It was seen as politically more convenient to have Greece inside rather than outside 'the club'. As such, one of the factors which led to the current pattern of crisis was a lack of political will to take hard decisions, a lack, if one likes, of political resilience in the face of tough political choices, coming back to the problem of lack of leadership already touched upon above. In fact, it could be argued that the unwillingness or unpreparedness to take big and hard decisions (such as leaving a willing member state out of the currency union, for example) are signs of a lack of confidence and/or conviction in the strength of one's own project. The EU has become an organization where 'muddling through' is a way of avoiding hard decisions rather than the result of pursing a clear strategic objective within a complex environment, a small but critical difference.

In many ways it could be argued that this lack of political resilience is the result of the extraordinary success of the EU over the decades both in political and economic terms and, therefore, the lack of urgency in constantly re-asking the why question. Politically, it is now inconceivable that any major European countries would go to war with one another. For European leaders from Monnet and Schuman to Mitterand and Kohl, this was the key point of European integration. For today's generation of leaders it is normal. Economically, too, Europeans, at least, had come to view prosperity, low inflation etc. as normal. In fact, in some countries one could even make a direct link between EU membership and economic prosperity, such as in Ireland, Portugal, Spain and Greece, coincidentally some of the same countries that are now suffering the worst economic crises. In the case of Ireland, for instance, Barnes (2009) has pointed out that 'the economic performance since the mid-1990s had been remarkable: GDP per capita growth averaged close to 5\% from 1995 to 2007'. Finally, the long-standing success of the EU also entrenched an institutional pattern of leadership by elites. For decades, the European Union essentially relied on passi$v e$ legitimacy, that is, acceptance by the population of decisions taken by 'Brussels' as Dinan (2004), amongst others, has shown. This worked for as long as things were going well but - and here the specific economic crisis has had a significant magnifying impact - is now being openly challenged by some which, as shown, has put considerable strain on the assumptions upon which European integration has always been based, such as solidarity. Schmitter (2012) even argued that all these issues pointed the way towards European disintegration. Within this context, there has also been a renewed debate about the supposed 'democratic deficit' at the heart of the European Union, as Sutherland (2012) has shown.

A lot more could be said on all of these issues.However, even this very cursory look shows that, far from being an economic crisis, asking what the current patterns of European integration are and represent shows that there have been significant changes to these patterns and, I would argue, an erosion of many of them. In basic terms, the 'European condition' of peace and prosperity in the Post-War period was seen as permanent and, almost, automatic. As 
${ }^{18}$ Debate with an EU memberstate ambassador during a seminar in 2012 . such, the basis for European integration was not questioned or challenged or significantly renewed.

Yet, clearly, perspectives on European integration have changed, just as the circumstances within which the process takes place, have changed. What has not been done is to adapt the European Union strategically to these changes.This brings us to the second question: So what (does it mean)?

In very basic terms, and following on from the paragraph above, the European Union, apart from facing a particular economic crisis, is also confronting a considerable strategic vacuum. Its propensity to think sequentially means that it has no answer to one critical question the author once put to one national ambassador of an EU member state: why solve the crisis? The answer given was revealing. The ambassador talked about the need to work jointly between member states to boost employment, to sharpen up the rules of the single currency, to bring public finances under control and about the need to save the single currency because the consequences of it failing would be unknowable but potentially catastrophic for the European Union. ${ }^{18}$

Yet, these are all particular answers for the particular economic problems. They reveal fear rather than a positive vision, enhancing the negative feedback which the EU has been receiving and generating. If there is no common vision, something which holds the block together, why not let Greece leave the euro in order to allow it to devalue its currency to get the economy going again? Why not, consequently, let other countries that so whish leave the euro, giving them the freedom to set their own interest rates?

Doing such things, obviously, has considerable risks simply because it has not been tried before. Whilst there are (weak) rules for governing the entry of countries into the euro and their behavior once inside the single currency, few to no provisions were made for governing the exit of a country from the single currency, as Böll et al. (2012) have shown. It would, therefore, be a journey into the unknown.

However, in the absence of a vision - some kind of idea about where the EU wants to go and why it is worth preserving and persisting with - the vacuum is filled by euro-skeptic voices pointing to the obvious problems large parts of the population are experiencing, pinning blame on the EU and her policies and offering simplistic but, on the face of it, attractive solutions to the crisis. One can see such patterns in Greece, in Italy and, in general terms, a steady rise of euro-skeptic parties across large parts of the European Union who are using the economic crisis to advance long-held broader arguments against the EU. Crucially, though, as Taggart and Szczerbiak (2013) have shown, this process began before the onset of the current economic crisis, pointing, once again, to the deeper roots of the current EU malaise.

So, what the European Union is confronting is a problem which the vacuum at the heart of its own thinking is reinforcing and perpetuating: the erosion of the common ground which has held the organization and its member states together over the decades. Instead, what are coming steadily to the fore are the differences that co-exist within the EU: between member states, between member states and EU institutions, between the different EU institutions, between different actors within these particular institutions etc. Over the decades, these differences have always existed and have indeed been necessary to allow for the EU to advance and adapt, as Geyer (2003) has shown, yet these differences always existed within the context of a clear aim, a clear and shared 
purpose about what European integration was about and what it was for, as shown above. This is currently absent because crisis-management is the permanent state of the European Union.

\section{So what does that mean in practical terms?}

The consequence of this is that, progressively, individual actors, member state governments, political parties, the media and citizens - have taken to filling the strategic void left by the EU, with the result that there seems to be now a self-reinforcing process of erosion of patterns that also seemed a 'given' and which have historically underpinned the core polices of the European Union. This is particularly clear in relation to the single market and its guarantee of freedom of movement of people, as Pascouau (2012) has pointed out. For instance, Denmark has taken measures to re-introduce border controls in certain cases, undermining the freedom of movement of European citizens. The UK government is pushing for a re-negotiation of its membership terms and has also identified freedom of movement as a key area of concern, something that even actors within the institutional structure of the EU are now accepting as legitimate. As already mentioned, in several countries, anti-EU parties now receive considerable numbers of votes, with the potential to influence government policy. Responding to this, several governments, including of traditionally pro-European countries such as the Netherlands, have started 'audits' of what the European Union does, arguing for a radical re-orientation of its activities, normally meaning doing less, leaving more to member states to determine individually. In fact, a summary of the Dutch government's recommendations done by EUobserver (2013) came to a full 20 pages.

This is not to say that an audit of EU activities would necessarily be a bad thing. For instance, what Cameron (2013) essentially argued was that the EU, to make itself relevant again in the world and in relation to its own citizens, should focus on its core activities, which he defined as the Eurozone's governance structures, European competitiveness, the single market and, as such, 'the gap between the EU and its citizens'. Cameron therefore made a specific connection between the Eurozone crisis and the crisis of the EU, which he defined both in practical (economic) terms and in terms of legitimacy, precisely some of the arguments put forward in this article. Crucially, however, he is using these problems to argue for a scaling-back of European integration. Those not in favor of such a refocusing of EU activities therefore need to engage with such an argument and develop a positive counter-argument. This has, so far, not occurred though it is to be hoped that audits and speeches such as Cameron's will at least kick-start a debate around such questions.

In short, the European Union is confronting a progressively unfavorable landscape on which to re-establish its legitimacy and, therefore, its political influence. In order to do so, however, it will need to adapt its approach and, crucially, its objectives.

\section{Now what (can we do)?}

Everything that has been said so far leads to one firm conclusion: the EU has to radically re-define of the crisis it is facing. This crisis will not end if and when the Eurozone crisis 'ends' and the economic situation stabilizes since it is only one part of a much broader picture. The EU, therefore, has to stop thinking in narrow, economic terms and it has to stop thinking sequentially. The reason it will not be able to first solve the economic crisis and then the political one is because, as I hope to have shown, both interact with - and sustain one 
${ }^{19}$ Remarks made to the author during a seminar in 2012 . another in complex and interdependent ways. As such, they are both part of the same general pattern that currently underpins the European Union.

The objective of European Union action has to be to change this general pattern through specific interventions. To do so in a way which enhances rather than undermines the coherence of its integration process it has to re-think its approach to change. As shown above, the EU is currently operating in a classic top-down way. It tells those countries in the most severe economic difficulties what they have to do in order to receive support. It has also defined an 'ideal' state towards which it wants to take these countries in terms of debtreduction and public sector reform. This has, as we have seen, led to significant public resistance and a further erosion of the general consensus which has sustained the EU over the years, underlining again the interdependent nature between the Eurozone and the EU crisis. The result is that the EU is trying to solve a short-term crisis without having defined clear long-term goals.

As a first step, therefore, the EU has to take the lead in a broad debate about its long-term objective. As shown, several countries are individually beginning a process of re-defining what they want European integration to be. It is critical that the EU takes a key role in these debates and begins to shape them. It has to act rather than react. Bearing in mind the complex nature of the EU structure, this in itself will not be a smooth process (nor should it be) but the organization needs to have a debate about what it wants to be.

Doing so will allow the European Union to do another key thing: de-centralize. As shown above, even within the confines of the economic crisis, 'every case is a case', that is to say, each case has its own particularities which depend critically on particular local circumstances. It is, therefore, critical that local actors be allowed to respond to the local boundary conditions they encounter.

This approach is equally valid for the broader question of the future of the EU. As shown above, the EU often currently takes decisions on micro-matters largely because it is unable to agree on the important strategic matters. As one Italian observer of EU affairs once put it to the author: 'Why does the EU have to regulate hunting in Italy ${ }^{19}$ It tries (but fails) to be a micromanager rather than being a strategic leader which, in turn, undermines public support for it by being seen to 'interfere' in essentially national issues, a key issue which also informed the Dutch 'audit' already referred to above.

Within a broadly defined strategic objective, the EU then can, and should, encourage the emergence of different approaches and policies across time and space in pursuit of this clearly defined broad strategic objective. Some authors, such as Acemoglu and Robinson (2012) call this a process of 'creative destruction' but in many ways it simply means the encouragement of experimentation and learning: what works where, when, how and why?

This leads to a third key issue: de-centralization and adaptation are critical simply because the outcome of any given policy-process is unknowable. Therefore, learning is a critical pre-requisite for correcting possible mistakes or possible unintended outcomes or consequences. As such, both the policies in respect of the economic crisis and the debates about the future of the European Union as a whole are not moving towards a pre-determined end-point. What is needed is continuous adjustment of an ongoing process. The EU therefore has to continuously ask questions about how this process is progressing. It should not pretend to have all the answers. 'How can we improve the current pattern 
of integration at European level' is an infinitely more productive way of engaging the various interested stakeholders than saying 'you have to follow us to this point because only this option will work', as has been done in relation to Greece, for example.

Now what can we do, as a question, therefore, refers much more to the type of process that is being used in order to address particular problems than coming up with definitive answers. Since the EU is a highly complex social system which evolves through the interaction of interdependent (and hence semiautonomous) agents across time and space and several levels of analysis, it is an illusion to think that the exact outcome of any given policy process and/or process of implementation can be controlled. There is too much uncertainty. As such, the EU has to adopt a posture of continuous inquiry, embedded within a clear context of strategic objectives without which there would be no purpose to the inquiry.

\section{VI . Conclusions}

The aim of this text has been to show that the crisis the EU is currently facing is far broader than the immediate economic crisis of the Eurozone and some of its member states in particular. It has been argued that the organization is also facing a strategic crisis in the sense that it does not know where it is going or what it wants to be. Critically, in the absence of such strategic objectives, it is much, much harder to solve the immediate crisis since there is no clear sense as to why that crisis should be solved within the context of the European Union. The strategic crisis of the EU and the particular crisis of the Eurozone are, therefore, intimately linked and sustain one another.

It has also been shown that, in the absence of a strategic objective and a clear sense of why the European Union exists, public support for - and the foundations of - the process of European integration erode. This process has been accelerated - but not started - by the current economic crisis.

In order to begin to address these problems this work has presented the concept of adaptive action and applied it to the EU and its current situation. Asking the question what, so what and now what, it has been shown that the European Union needs to think of its development as an ongoing process of questioning, learning and adjusting in order to change the patterns that underpin the process of integration. Asking such questions and standing in permanent inquiry would allow the EU to act as a strategic leader rather than the overloaded micromanager it is trying to be at the moment. The aim needs to be to make the EU politically more resilient than it has proven to be so far.

The question of how to create a politically more resilient EU will require a lot more work and research. Ways will have to be found to make the institutional framework more flexible in the face of severe crises and more alert to the warning signs of a coming crisis, i.e. signs that point to an erosion of the existing patterns sustaining integration. To do so, it may well be necessary to do an 'audit' of EU activities of the type that several national governments are currently conducting. However, it is essential that the EU lead such a debate rather than follow it and that, again, such an audit be guided by some clear principles. As has been argued, such principles should include a commitment to de-centralization, as well as a focus on the 'big' issues which can and will make a positive difference to people's lives rather than the current obsession 
with regulating lots of small issues that can perfectly well be dealt with at national or even local level.

All of this may and should eventually lead to dealing with the biggest issue of all: why should the European Union still exist in the $21^{\text {st }}$ century? It seems a simple question, but a clear answer is needed as a matter of urgency.

Kai Lehmann (klehmann@usp.br) é PhD em Relações Internacionais pela Universidade de Liverpool (Reino Unido) e professor do Instituto de Relações Internacionais da Universidade de São Paulo (USP).

\section{References}

Acemoglu, D.; Robinson, J.A. 2012. Why Nations Fail: The origins of power, prosperity and poverty. New York: Crown Business.

Barnes, S. 2009. 'Ireland's economic outlook'.In OECD. Economic Survey of Ireland, Nov. Available at http://oecdobserver. org/news/archivestory.php/aid/3129/Ireland_92s_economic_outlook.html. Accessed 1.June.2014.

Bayomi, T.; Eichgreen, B. 1993. Shocking Aspects of European Monetary Union. In F. Torres; F. Giavazzi, eds. The Transition to Economic and Monetary Union. Cambridge: Cambridge University Press.

Berggrunen, N.; Gardels, N. 2013. The Next Europe: Towards a Federal Union. Foreign Affairs, July-Aug., pp. 134-142.

Bittner, J. 2010. So nicht, Europa. Die drei grossen Fehler der EU. München: DTV Premium.

Blyth, M. 2013. The Austerity Delusion. Foreign Affairs, May-June, pp. 41-56.

Böll, S.; Reiermann, C.; Sauga, M.; Wiegrefe, K. 2012. Operation Self-Deceit: New documents shine light on Euro birthdefects. Spiegel Online. Available at http://www.spiegel.de/international/europe/euro-struggles-can-be-traced-to-ori gins-of-common-currency-a-831842.html. Accessed 29.May.2014.

Cameron, D. 2013. Prime Minister David Cameron's Speech on the Future of the EU and the UK's Relationship with it. Office of the Prime Minister. Available at https://www.gov.uk/government/news/david-camerons-eu-speech-2. Accessed 1.June.2014.

Cini, M.; Borragán, N.P. 2013. European Union Politics. $4^{\text {th }}$ ed. Oxford: Oxford University Press.

Copsey, N.; Haughton, T. 2012. Desperate, but not Serious: The EU in 2011. Journal of Common Market Studies, 50(Annual Review), pp. 1-5.

Dinan, D. 2004. Europe Recast: A history of European Union. Basingstoke: Palgrave Macmillan.

Eoyang, G.H.; Holladay, R.J. 2013. Adaptive Action: Leveraging uncertainty in your organization. Stanford: Stanford Business Books.

Fox, B. 2013. Survey Reveals Widening EU North-South Divide. EUobserver, 24.July. Available at http://euobserver.com/ political/120958. Accessed 1.June.2014.

Geyer, R. 2003. European Integration, Complexity and the Revision of Theory. Journal of Common Market Studies, 41(1), pp. 15-35.

Hodson, D.; Puetter, U. 2013. The European Union and the Economic Crisis. In M. Cini.; N.P. Borragán, eds. European Union Politics. Oxford: Oxford University Press.

Kramer, S.P. 2012. The Return of History in Europe. Washington Quarterly, 35(4), pp. 81-91.

Krugman, P. 2012. End this Depression Now. London: W.W. Norton \& Company.

Jo Johnson, M.P.; Jungclaussen, J.; Nicolaïdis, K.; Peet, J. 2012. Chatham House Debate: Ever Closer Union? The future of the European Project. Chatham House. Available at http://www.chathamhouse.org/events/view/182346. Accessed 1.June.2014.

Lane, P.R. 2012. The European Sovereign Debt Crisis. Journal of Economic Perspectives, 26(3), pp. 49-68.

Lehmann, K. 2012. Mérito obscurecido. Ciência Hoje, 50(299), p. 24.

Lichtenstein, B.; Uhl-Bien, M.; Marion, R.; Seers, A.; Orton, J.D. 2006. Complexity Leadership Theory: An interactive perspective on leading in complex adaptive systems. Emergence, 8(4), pp. 2-12.

Mallaby, S. 2012. Europe's Optional Catastrophe. The Fate of the Monetary Union Lies in Germany's Hands. Foreign Affairs, Jul.-Aug. Available at http://www.foreignaffairs.com/articles/137694/sebastian-mallaby/europes-optional-catastrophe. Accessed 1.June.2014.

Manners, I. 2008. The Normative Ethics of the European Union. International Affairs, 84(1), pp. 65-80.

Milne, R. 2013. Euro Fiscal Union Undermines EU. Financial Times, 1.Feb. Available at http://www.ft.com/cms/s/0/ 3672723e-7aa7-11e2-9cc2-00144feabdc0.html\#axzz2ZmhTCb3z. Accessed 22.Jul.2014.

Nelson, R.M; Belkin, P.; Mix, D.E.; Weiss, M.A. 2012. The Eurozone Crisis: Overview and issues for Congress. Congressional Research Service Issue Brief. Washington, D.C.: Congressional Research Service.

Nugent, N. 2010. The Government and Politics of the European Union. $7^{\text {th }}$ ed. Basingstoke: Palgrave Macmillan.

Pascouau, Y. 2012. Schengen Area of Freedom of Movement Being Undermined. Public Service Europe, 6.July. Available at http://www.notre-europe.eu/media/yp_090712_publicserviceeurope_01.pdf?pdf=ok. Accessed 1.June.2014. 
Schmitter, P. 2012. European Disintegration? A Way Forward. Journal of Democracy, 23(4), pp. 39-48.

Serricchio, F.; Tsakatika, F.; Quaglia, L. 2013. Euroskepticism and the Global Financial Crisis. Journal of Common Market Studies, 51(1), pp. 51-64.

Subacchi, P.; Pickford, S. 2012. Broken Forever? Addressing Europe's multiple crises. Chatham House Briefing Paper, IE BP 2012/01.

Sutherland, P. 2012. The Euro's Democratic Deficit. The New York Times, 29.May. Available at http://www.nytimes.com/ 2012/05/30/opinion/the-euros-democratic-deficit.html?pagewanted=all\&_r=0. Accessed 1.June.2014.

Taggart, P.; Szczerbiak, A. 2013. Coming in from the Cold? Euroscepticism, Government Participation and Party Positions on Europe. Journal of Common Market Studies, 51(1), pp. 17-37.

Tooze, A. 2012. Germany's Unsustainable Growth. Austerity Now, Stagnation Later. Foreign Affairs, Sept.-Oct. Available at http://www.foreignaffairs.com/articles/137834/adam-tooze/germanys-unsustainable-growth. Accessed 1.June.2014.

Tsoukalis, L. 2011. The Shattering of Illusions - And What Next? Journal of Common Market Studies, 49(Annual Review), pp. 19-44.

Wallace, H.; Pollack, M.A.; Young, A.R. 2010. Policy-Making in the European Union. $6^{\text {th }}$ ed. Oxford: Oxford University Press.

Walton, N.; Zielonka, J. 2013. The New Political Geography of Europe. London: European Council on Foreign Relations.

Wessels, B. 2007. Discontent and European Identity: Three types of Euroscepticism. Acta Politica, 42, pp. $287-306$.

\section{Other sources}

EUobserver. 2013. Testing European Legislation for Subsidiarity and Proportionality - Dutch list of points for action. Available at http://euobserver.com/media/src/37f91104ec1fbecfdbb5685948bfa8c4.pdf. Accessed 1.June.2014.

European Central Bank. 2014. Key Dates of the Financial Crisis (since December 2005). Available at https://www.ecb.euro pa.eu/ecb/html/crisis.en.html. Accessed 2.June.2014.

European Commission. 2013. Standard Eurobarometer, 79, pp. 1-4.

Finanzkrise: Euro Länder häufen neue Schulden an. 2013. Spiegel Online, 22.July. Available at http://www.spiegel.de/wirts chaft/soziales/euro-zone-schuldenstand-steigt-weiter-an-a-912383.html. Accessed 26.May.2014. Accessed 2.June.2014.

Global Property Guide. 2014. Ireland Housing Market Continues to Recover, Dublin in mini-bubble? Available at http:// www.globalpropertyguide.com/Europe/ireland/Price-History. Accessed 1.June.2014.

No Going Back. 2010. The Economist, 13.May. Available at http://www.economist.com/node/16116773. Accessed 29.May.2014.

Till default do us part. 2013. The Economist, 8.Jun. Available at http://www.economist.com/news/finance-and-economics/ 21579024-half-hearted-banking-union-raises-more-risks-it-solves-till-default-do-us. Accessed 1.June.2014.

Trading Economics. 2014a. Greece GDP. Available at http://www.tradingeconomics.com/greece/gdp. Accessed 1.June.2014. . 2014b. Spain Unemployment Rate. Available at http://www.tradingeconomics.com/greece/gdp. Accessed 1.June.2014.

\section{RESUMO}

É comum, mesmo na imprensa europeia, tratar a atual crise da União Europeia exclusivamente como uma crise econômica. O presente artigo pretende mostrar que esse foco não está somente errado mas perigoso para o desenvolvimento futuro da organização em si. O artigo sustentará que a crise econômica simplesmente agravou - e muito - uma crise de legitimidade pela qual a União Europeia está passando há algum tempo. Mostrando que as tendências antieuropeias que estão se espalhando pelos países europeus ameaçam o futuro do projeto de integração europeia, o artigo fará sugestões para reformas na atuação da União Europeia e alerta pela necessidade de finalmente elaborar mais uma vez um argumento coerente para justificar a continuação do projeto europeu, colocando a população europeia no coração do processo político europeu em vez de somente se aplicarem medidas de austeridade. A pesquisa foi um estudo qualitativo, baseada numa revisão da literatura existente sobre a crise e entrevistas com especialistas e políticos da União Europeia. O artigo estabeleceu que a União Europeia está passando por múltiplos crises, tanto no nível político, quanto no nível econômico, de uma forma interdependente. O artigo também mostra que existe um reconhecimento dessa crise por parte de alguns oficiais da União Europeia mas também uma incapacidade de agir, por dificuldades políticas, assim como um entendimento errado da natureza da crise sendo enfrentada. A originalidade do artigo se dá pela definição da crise da União Europeia como uma crise política E econômica que interagem em um processo contínuo. O artigo mostra que se trata de um processo de "ação adaptativa", baseada nas perguntas "what", "so what", "now what?" Essas perguntas têm implicações importantes para as ações da União Europeia em resposta à crise atual, que o artigo aborda. Sendo assim, o artigo propôs uma visão diferente e original sobre o que representa a crise atual e o que tem que ser feita em resposta a ela.

PALAVRAS-CHAVE: União Europeia; crises múltiplas; ação adaptativa; austeridade; integração Europeia. 